\title{
Age and archaeological implications of Xitle volcano, southwestern Basin of Mexico-City
}

\author{
C. Siebe* \\ Instituto de Geofísica, Universidad Nacional Autónoma de México, Coyoacán, C.P. 04510, Mexico, D.F., Mexico
}

Received 23 November 1999; revised 6 April 2000; accepted 11 April 2000

\begin{abstract}
The Pedregal lavas are fresh, well-exposed basaltic flows erupted from the Xitle scoria-and-cinder cone in the southwestern part of the Basin of Mexico. These lavas cover an area of $70 \mathrm{~km}^{2}$ and were emplaced over pyramids and other buildings (e.g. Cuicuilco and Copilco archaeological sites). Today, a part of Mexico-City (including the National University) is built on the flows.

Initial strombolian activity produced an ash fallout layer, which was immediately followed by effusive emplacement of lava flows. The Xitle cone grew on the north-facing slope of Ajusco volcano, and lava flowed down to the N-NE until it reached the basin floor.

More than 30 radiocarbon dates have been obtained by several workers on charcoal samples from beneath the lava, and several ages for the eruption have been proposed from these dates. Most dated samples were not directly produced by Xitle's eruption but instead are artifacts of human activity that predates the eruption. Thus, these ages (mostly about $2000 \mathrm{BP}$ ) are older than the eruption. A new age of $1670 \pm 35$ years BP (AD 245-315) obtained on charcoal samples collected just beneath the lavas is favored for the Xitle eruption. These samples originated by ignition of vegetation during the emplacement of hot scoriaceous tephra. The new age is within the Classic period of Mesoamerican archaeology, whereas the earlier reported ages are at the end of the Preclassic. The new age carries important implications for the timing of population shifts within the Basin of Mexico. (C) 2000 Elsevier Science B.V. All rights reserved.
\end{abstract}

Keywords: Xitle volcano; Basin of Mexico; scoria-and-cinder; Cuicuilco

\section{Introduction}

Xitle Volcano, located at the southwestern limits of the Basin of Mexico produced the "El Pedregal" lava flows, which engulfed and covered several Prehispanic settlements, including famous Cuicuilco pyramid (Figs. 1-4). Prior to the eruption, Cuicuilco was situated on a deltaic plain of a stream draining the slopes

\footnotetext{
* Corresponding author. Tel.: +52-5-622-4119/4146; fax: +525-550-2486.

E-mail address: csiebe@tonatiuh.igeofcu.unam.mx (C. Siebe).
}

of Ajusco stratovolcano. The eruption forced many people to abandon their villages and represents a documentable example of a volcanic disaster in this region. The youthful appearance of Xitle volcanic cone in conjunction with the discovery of archaeological material underneath Xitle lava flows prompted many attempts to determine the numerical age of eruption. Due to the lack of written accounts describing Xitle's eruption, the age of the volcano can only be determined using the radiocarbon dating method. After the initial date of $2422 \pm 250$ years BP (C-200) reported by Arnold and Libby (1951), many 
additional ages have been obtained from organic material collected several $\mathrm{cm}$ below the lava (Table 1). However, these ages vary by more than 1000 years and thus do not pinpoint the age of the eruption.

\section{Geologic setting}

The Trans-Mexican Volcanic Belt (TMVB) is an E-W-trending zone located between 19 and $20^{\circ} \mathrm{N}$ latitude that extends ca. $1000 \mathrm{~km}$ from the Pacific to the Gulf of Mexico (Fig. 1). Its origin is related to the subduction of the Cocos Plate beneath the North American Plate. Xitle monogenetic basaltic scoriaand-cinder cone is located within the Sierra del Chichinautzin Volcanic Field (SCVF) in the central part of the TMVB. The SCVF is a volcanic highland elongated in an $\mathrm{E}-\mathrm{W}$ direction that extends from the western slope of Popocatépetl stratovolcano in the east to the eastern part of the Toluca valley in the west (Fig. 1). This volcanic field represents the volcanic front of the TMVB in this area and is on the continental drainage divide that separates the Basin of Mexico-City from the valleys of Cuernavaca and Cuautla to the south. According to Fries (1962) the Basin of Mexico drained to the south before the Pleistocene. Since then, formation of the SCVF sealed the basin to the south (Mooser, 1963).

The SCVF has one of the highest concentrations of monogenetic volcanoes in the entire TMVB, and includes more than 200 overlapping Quaternary cinder cones, associated lava flows, tephra sequences, and lava shields intercalated with alluvial sediments that cover an area of approximately $2500 \mathrm{~km}^{2}$ (Bloomfield, 1975; Martin del Pozzo, 1982; Lugo Hubp, 1984). Volcanic rocks in this area are mostly andesites with

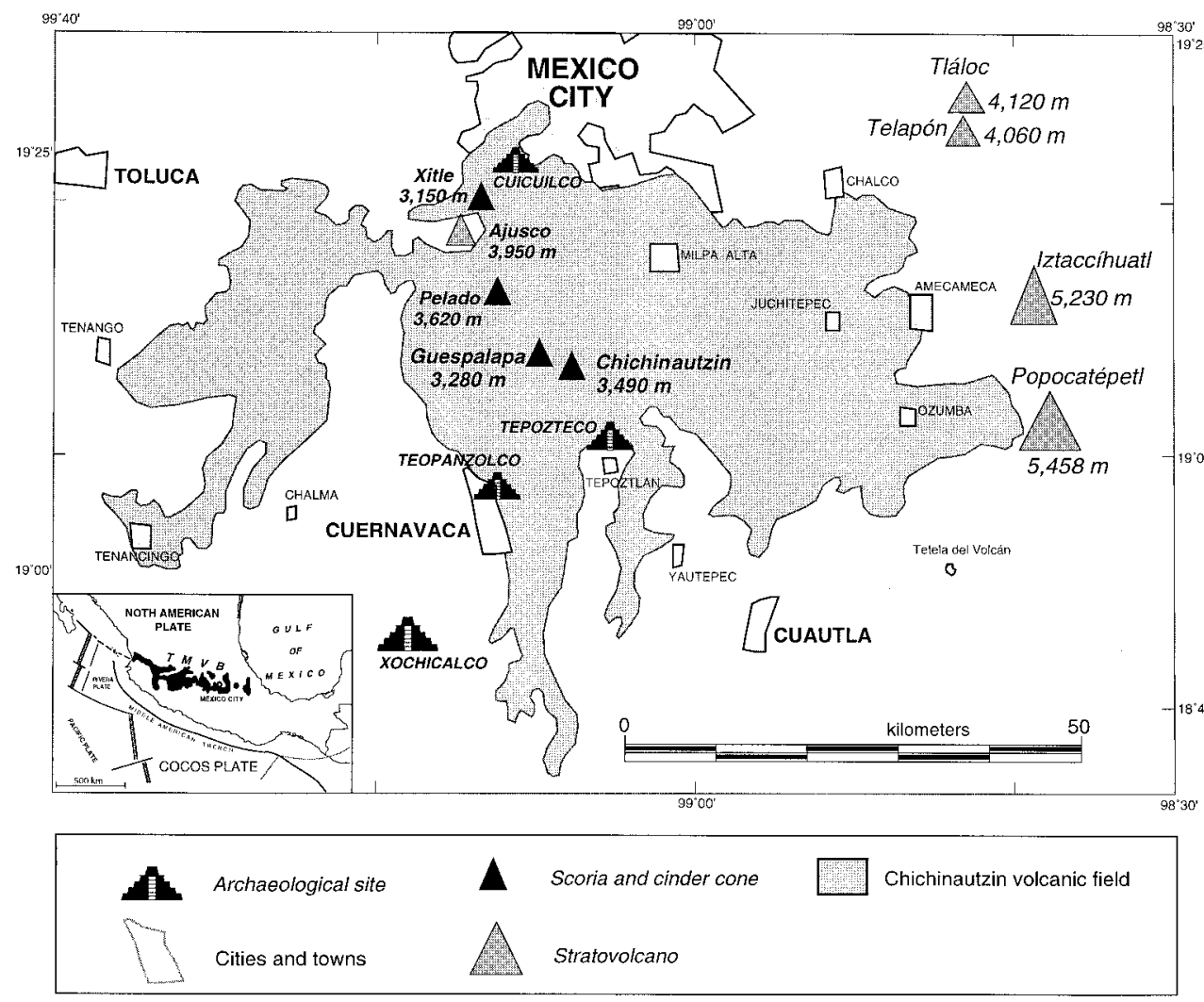

Fig. 1. Sketch map showing the Sierra Chichinautzin volcanic field and location of Xitle basaltic scoria cone at the SW margin of the Basin of Mexico. 
subordinate basalts and dacites that define a calc-alkaline series (Gunn and Mooser, 1971; Swinamer, 1989; Wallace and Carmichael, 1999).

Paleomagnetic measurements on volcanic rocks from the SCVF (Mooser et al., 1974; Herrero and Pal, 1978; Urrutia Fucugauchi and Martin del Pozzo, 1993) indicate that most exposed rocks were produced during the normal Bruhnes Cron and are therefore younger than $0.73-0.79 \mathrm{Ma}$. This is not surprising, since most of the cinder cones and lavas display very young morphological features and are covered by and intercalated with poorly developed soils. Kirianov et al. (1990) dated soils below and above lava flows and scoria fall sequences of several cones within or adjacent to Xitle and concluded that Xitle must be younger than $3250 \pm 50$ years BP (Table 1, IVAN-495).

\section{Xitle scoria cone and El Pedregal lavas}

Xitle $($ xictle $=$ navel in Náhuatl, the language spoken by the Aztecs) is a scoria cone ( $3150 \mathrm{~m}$ asl) with a height of $140 \mathrm{~m}$ above surrounding ground and a basal diameter of $500 \mathrm{~m}$. Some $100 \mathrm{~m}$ westward is a smaller scoria cone named Xicontle. Both are located on the northeastern slopes of extinct Ajusco volcano (3950 m asl), whose summit is the highest peak in the area (Figs. 2 and 3). Cervantes and Molinero (1995) showed that Ajusco volcano collapsed northward to produce the Zacatépetl debris avalanche deposit. The deposit has an estimated runout distance of $16 \mathrm{~km}$, a volume of $1.4 \mathrm{~km}^{3}$, and an age younger than $3.37 \pm 0.27 \mathrm{Ma}$ (Cervantes and Molinero, 1995). This deposit formed an undulating and hummocky terrain, which today is almost covered by Xitle's lavas.

The eruption of Paricutín (1943-1953) in the State of Michoacán (e.g. Luhr and Simkin, 1993) could be envisaged as a modern analogue of Xitle. The lava and ash from Paricutín destroyed the village of Parangaricutiro, leaving only the spires of the local church rising above the dark rock as monuments of the village's presence. In much the same way, Xitle tephra and

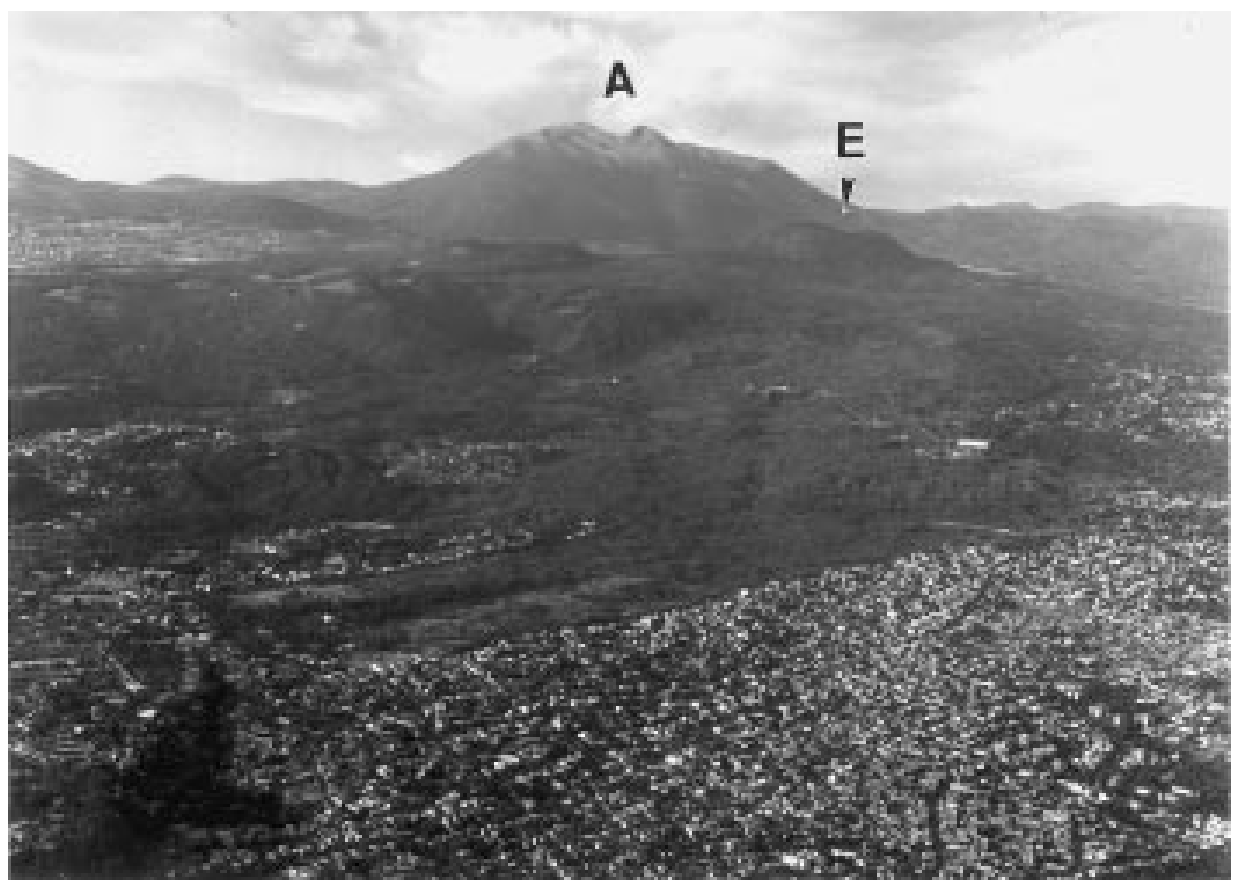

Fig. 2. Aerial view of Ajusco stratovolcano (3950 m asl) (A), and Xitle scoria cone (3150 m asl) (E), located at the SW margin of the Basin of Mexico. Xitle's lavas flowed mostly towards the N and NE into the basin. Today the flows are probably the most densely populated young lavas on earth. Photograph taken December 29, 1994. 


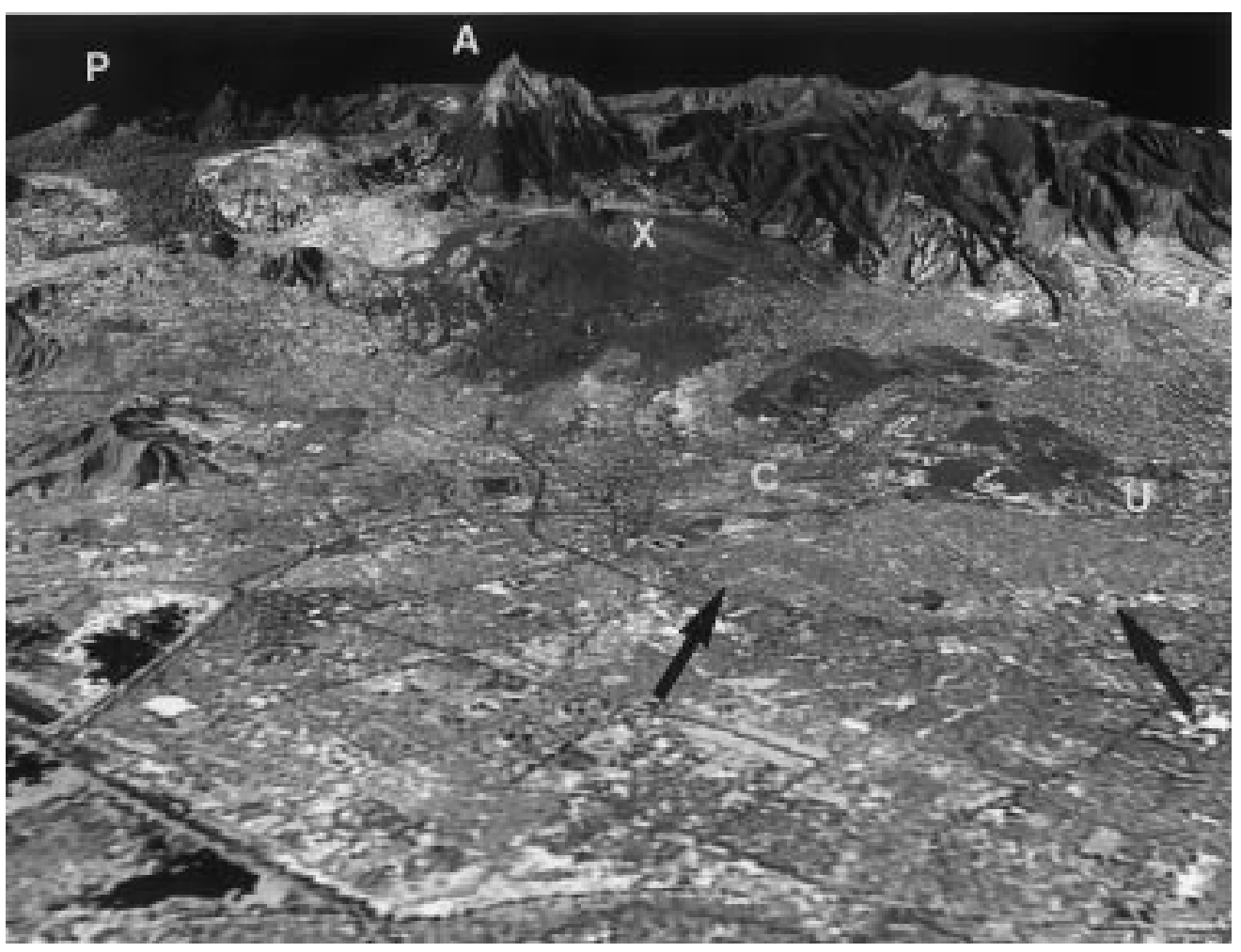

Fig. 3. Landsat TM perspective view showing Xitle volcano and extent of the El Pedregal lava flows. $\mathrm{A}=\mathrm{Ajusco}, \mathrm{X}=\mathrm{Xitle}, \mathrm{C}=\mathrm{Cuicuilco}$, $\mathrm{U}=\mathrm{UNAM}$-campus, and $\mathrm{P}=$ Pelado volcano. Arrows denote margins of the Xitle lava flows.

lava covered a community of secular and monumental structures. One of these buildings, the Cuicuilco circular pyramid, protruded above the lava (Fig. 4). The nature of this hill was first demonstrated in 1922 (Cummings, 1923a,b,c). Since then, investigations have shown that the Cuicuilco pyramid and related buildings are the oldest known evidence of urbanism in the highlands of Central Mexico. Cuicuilco proper rises about $16 \mathrm{~m}$ above its base and has a diameter of ca. $130 \mathrm{~m}$.

While the Xitle cone was growing on the debris avalanche deposit from Ajusco, lava flowed towards the $\mathrm{N}$ and $\mathrm{NE}$ along barrancas. Only the highest hummocks of the debris avalanche, such as Cerro Zacatépetl, were not covered by Xitle's lava (Fig. 5). At the end of Xitle's eruption the lavas covered a total of $70 \mathrm{~km}^{2}$ and extended into the lacustrine Basin of Mexico (2240 m asl), where at some places they flowed into water, as evidenced by the formation of pillow lavas near Peña Pobre (Delgado et al., 1998; González et al., 2000).
The longest flow descended $900 \mathrm{~m}$ and reached $12 \mathrm{~km}$ from the crater. Most flows advanced through lava tubes, and are compound pahoehoe units that range in thickness from 0.2 to $13.0 \mathrm{~m}$. Flow units are highly vesicular in their upper third and almost non-vesicular in their lower two thirds apart from a vesicular layer containing pipe vesicles in the basal 0.5-1.0 m (Cañón-Tapia et al., 1995). The lava flows display a young morphology with little vegetation cover and well-preserved flow structures such as lava channels, pressure crests, and tumuli (Ordoñez, 1890; Waitz and Wittich, 1910). The Xitle lavas are dark gray basalt that contains plagioclase and olivine phenocrysts. In addition, Wittich (1919) reported xenocrystic quartz in the Xitle lavas and attributed their origin to the incorporation of basement rocks during magma ascent.

Around the margins of the lava, a persistent layer of gray ash suggests that the eruption began with lava fountaining (Ordoñez, 1939). Cervantes and Molinero 


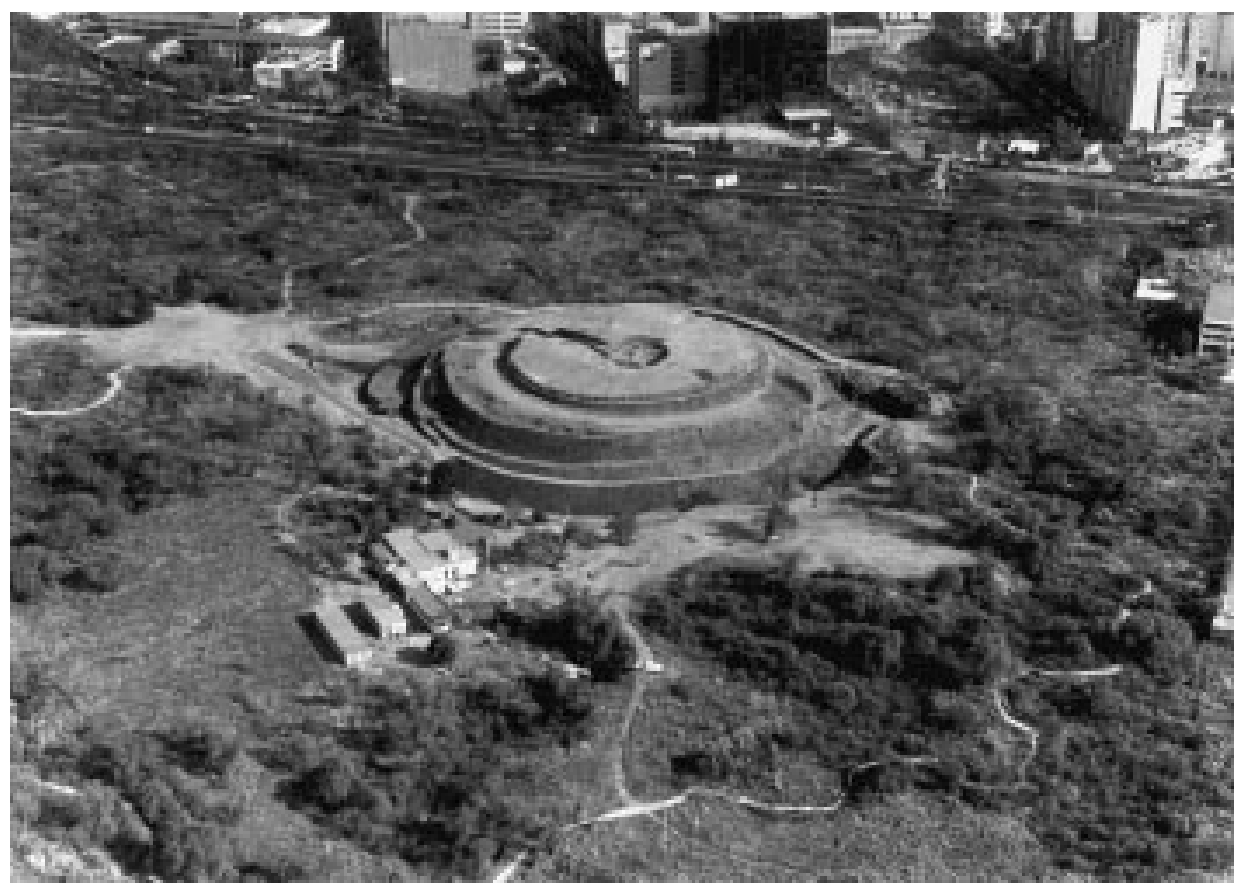

Fig. 4. Aerial view toward the north of the Cuicuilco pyramid surrounded by Xitle lava flows coming from the southwest (lower left corner). The circular structure with a diameter of ca. $130 \mathrm{~m}$ was first explored by Cummings between 1922 and 1925. Explosives were used for lava removal and the outer walls of the pyramid were partly destroyed. The walls visible today belong to an interior part of the pyramid. Photograph taken 4 April 1997.

(1995) estimated eruptive column heights up to $11.2 \mathrm{~km}$ above the crater. They concluded that Xitle produced $0.96 \mathrm{~km}^{3}$ of lava and $0.12 \mathrm{~km}^{3}$ of ash. The ash was mostly dispersed towards the $\mathrm{S}$ and $\mathrm{W}$. Cervantes and Molinero (1995) assigned a Volcanic Explosivity Index (VEI) (Newhall and Self, 1982) of 4 to Xitle's eruption, although in my opinion this estimate is much too high and should rather be located somewhere between VEI 2 and 3. Field observations indicate that Xitle's lava had a low viscosity and that the eruption was mostly effusive. To date, no soil or ash has been observed within Xitle's lava flow units.

Recently, Delgado et al. (1998) published a new geologic map and stratigraphy for Xitle volcano in which they distinguish up to 7 major lava flow units. In addition, they mention the existence of pyroclastic flow deposits associated to Xitle, which I was unable to identify in the field.

The duration of Xitle's eruption is not known but historic eruptions of similar volcanoes in the TMVB suggest short periods of activity, of the order of a decade or so (e.g. the 1943-1953 Paricutín; Foshag and González, 1956; Luhr and Simkin, 1993; or the 1759-1774 Jorullo eruptions; Bullard, 1984).

Most scientists consider Xitle to be the youngest volcano within the SCVF. Therefore, its eruption is viewed as the most recent to have an impact on the Valley of Mexico and be witnessed by humans (e.g. Scandone, 1979).

\section{Historical background and archaeological excavations}

Most of the archaeological research in the SCVF has concentrated on sites related to Xitle volcano and its eruptive products. During the 19th century bandits found refuge in Xitle lava tubes. During the first decades of the 20th century the lavas were extensively quarried, which resulted in the discovery of much ancient pottery underneath the lavas. Since then, Xitle has been studied in greater detail as it became 


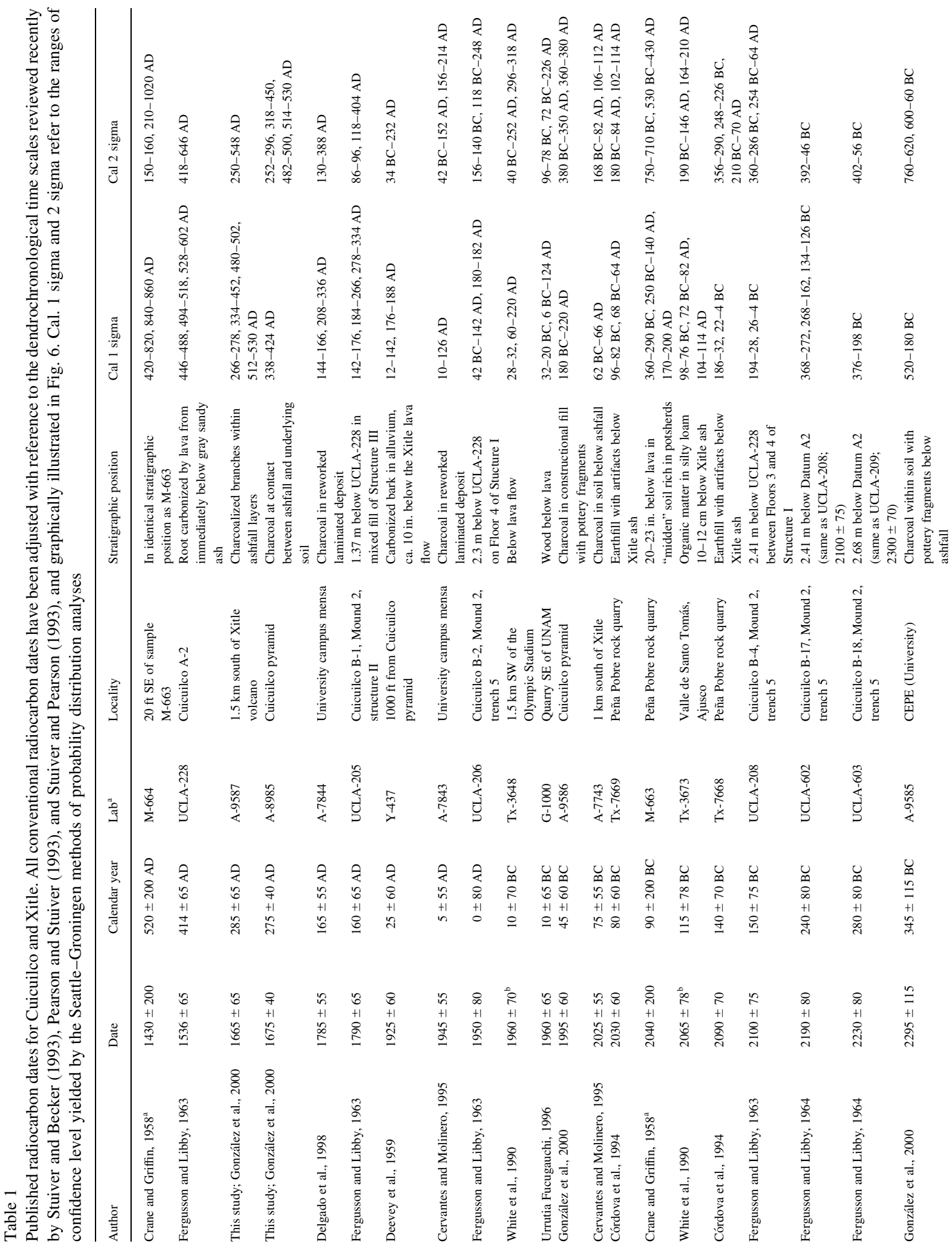




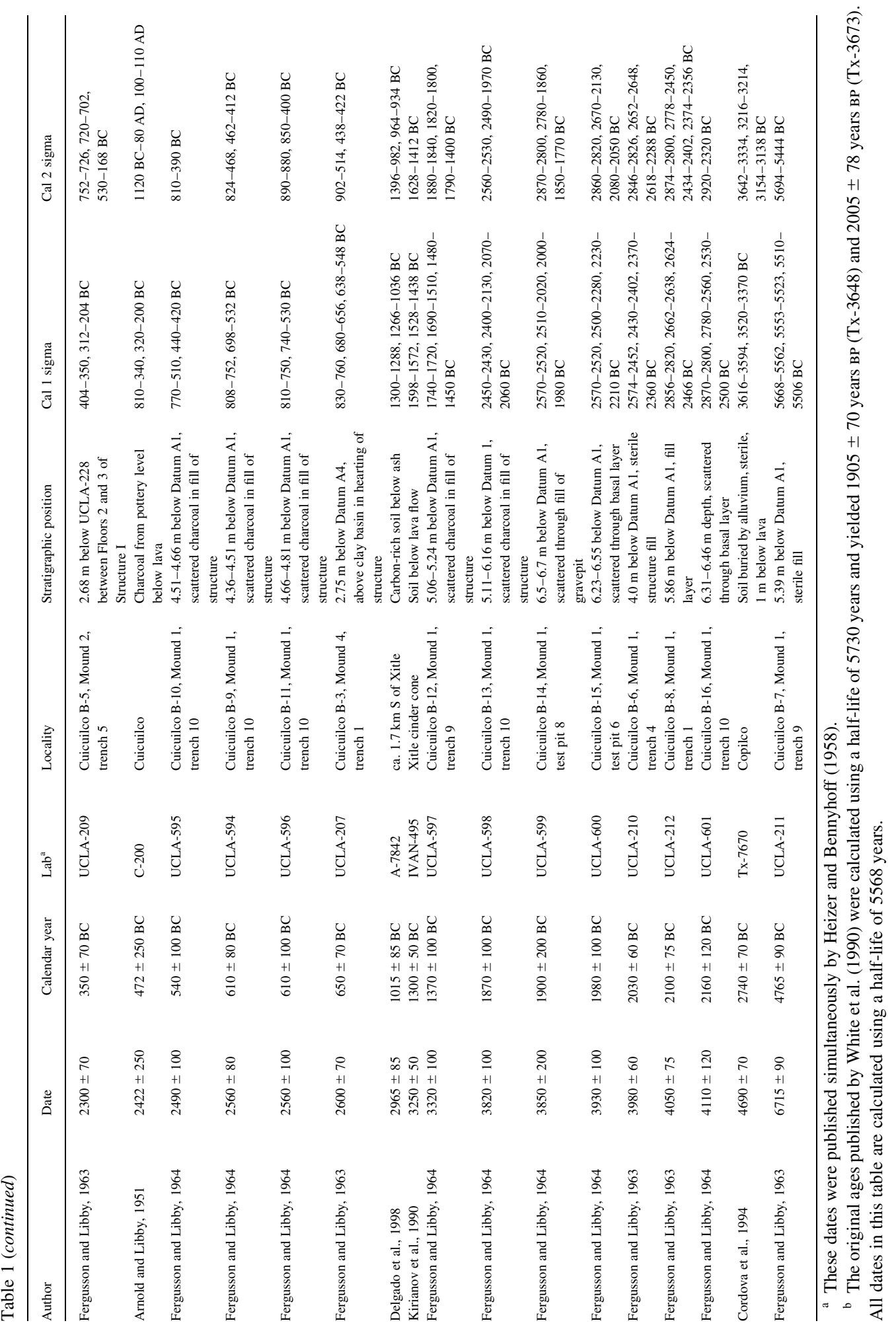




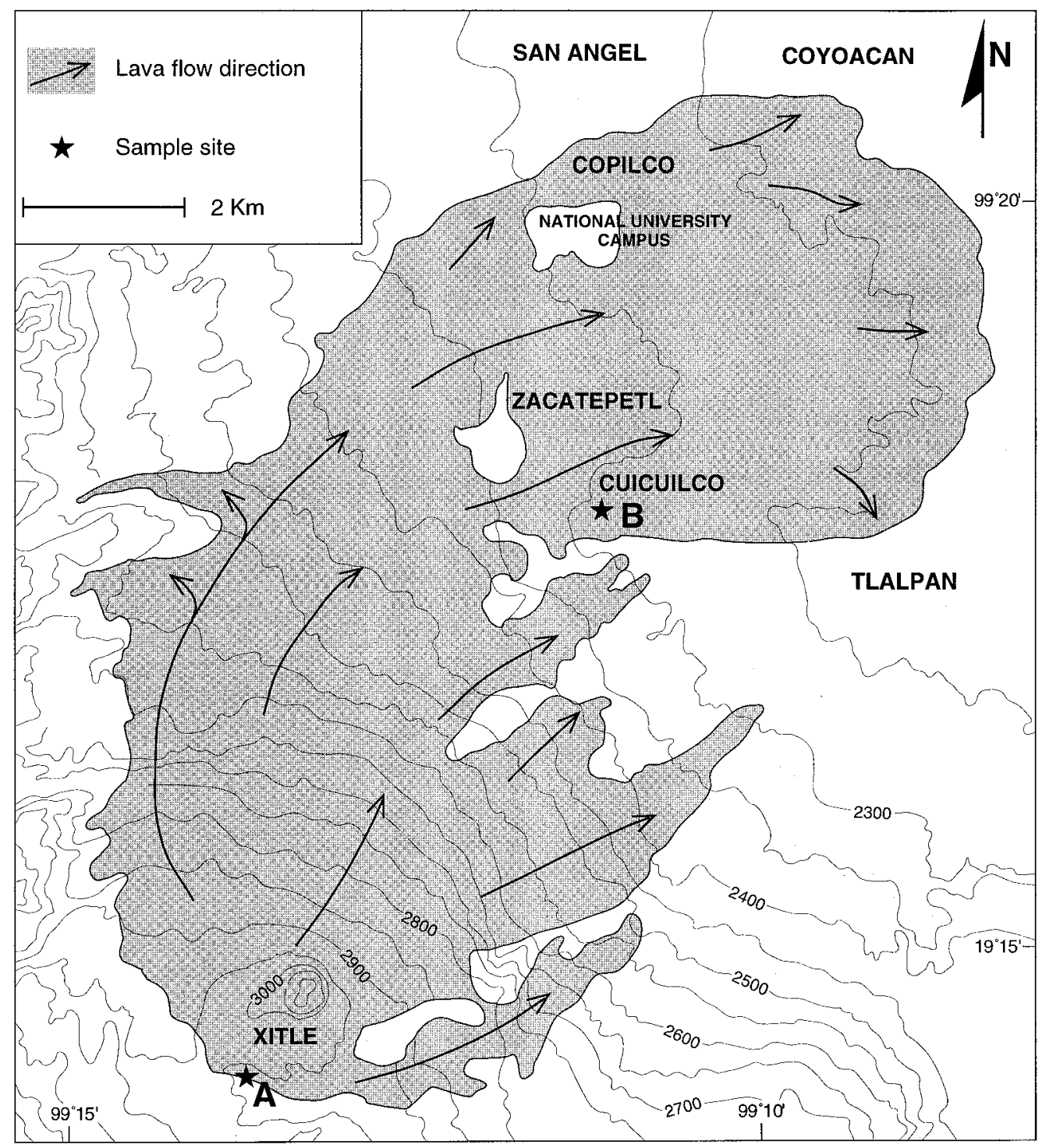

Fig. 5. Sketch map showing Xitle volcano and extent of El Pedregal lava flows. Location of stratigraphic sections A and B shown in Fig. 7 are marked on the map.

clear that its lavas destroyed and buried the ancient prehispanic town of Cuicuilco, located $7 \mathrm{~km} \mathrm{NE}$ of the cone. Today, Xitle's lavas are probably the most densely populated flows on earth.

Ordoñez $(1890,1895,1907)$, Waitz and Wittich (1910), Wittich (1910, 1916, 1919), Cuervo-Márquez (1928), Maldonado Koerdell (1954), Schmitter (1953) and Badilla-Cruz (1977) discussed the petrography of the Xitle flow, described its volcanic structures (e.g. tumuli and lava tubes), and mentioned human bones and ancient pottery buried by the lava flows. Beyer (1918), Gamio (1920), Cummings (1923a,b,c, 1926, 1933), Díaz-Lozano (1925a,b), Kroeber (1925), Nuttall (1925) and Noguera (1938) were the first to carry out scientific excavations at the archaeological sites of Copilco, Coyoacán, and Cuicuilco, all partly covered by Xitle's lava. Based on their findings they concluded that an "Ancient" culture that preceded the 


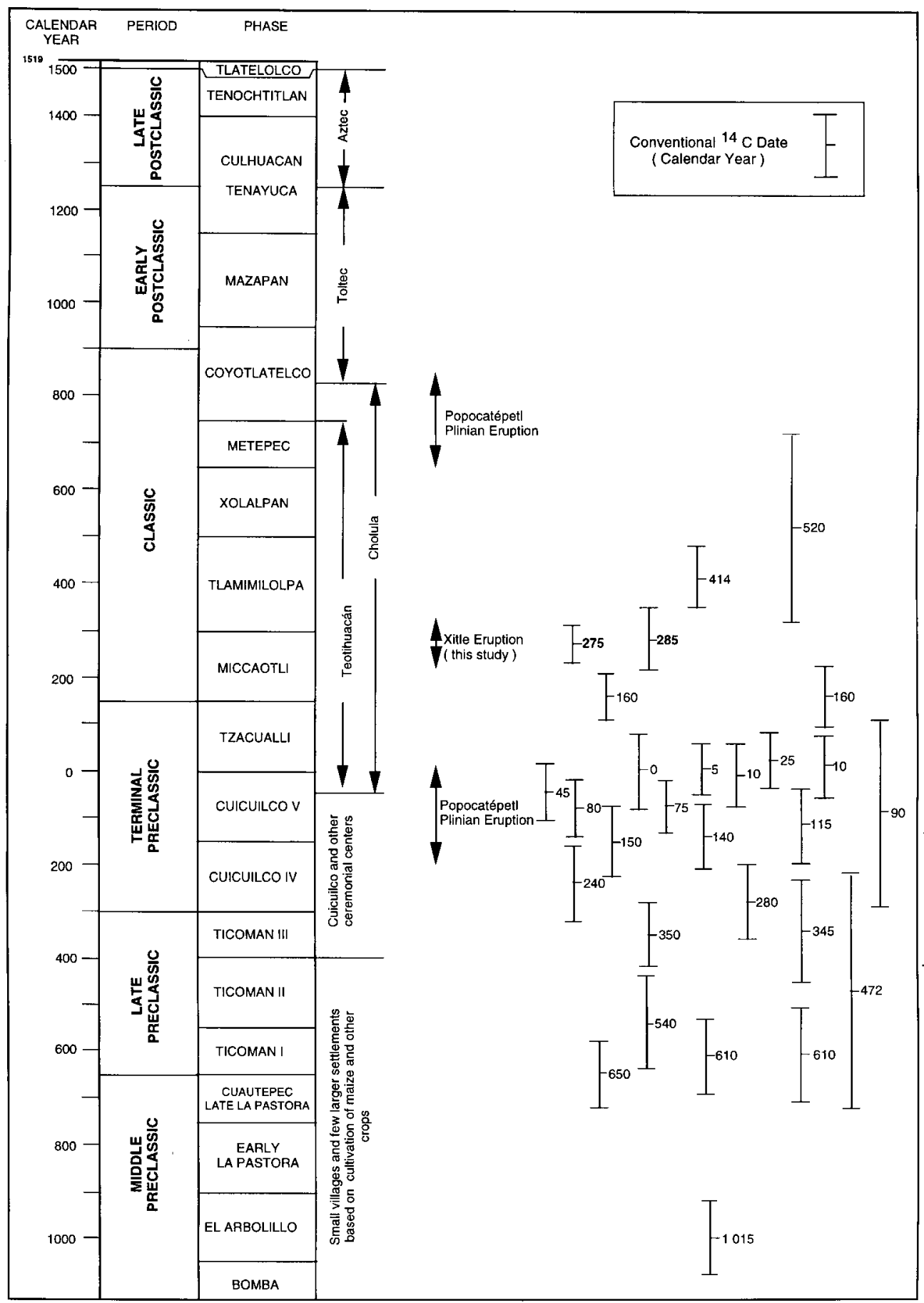




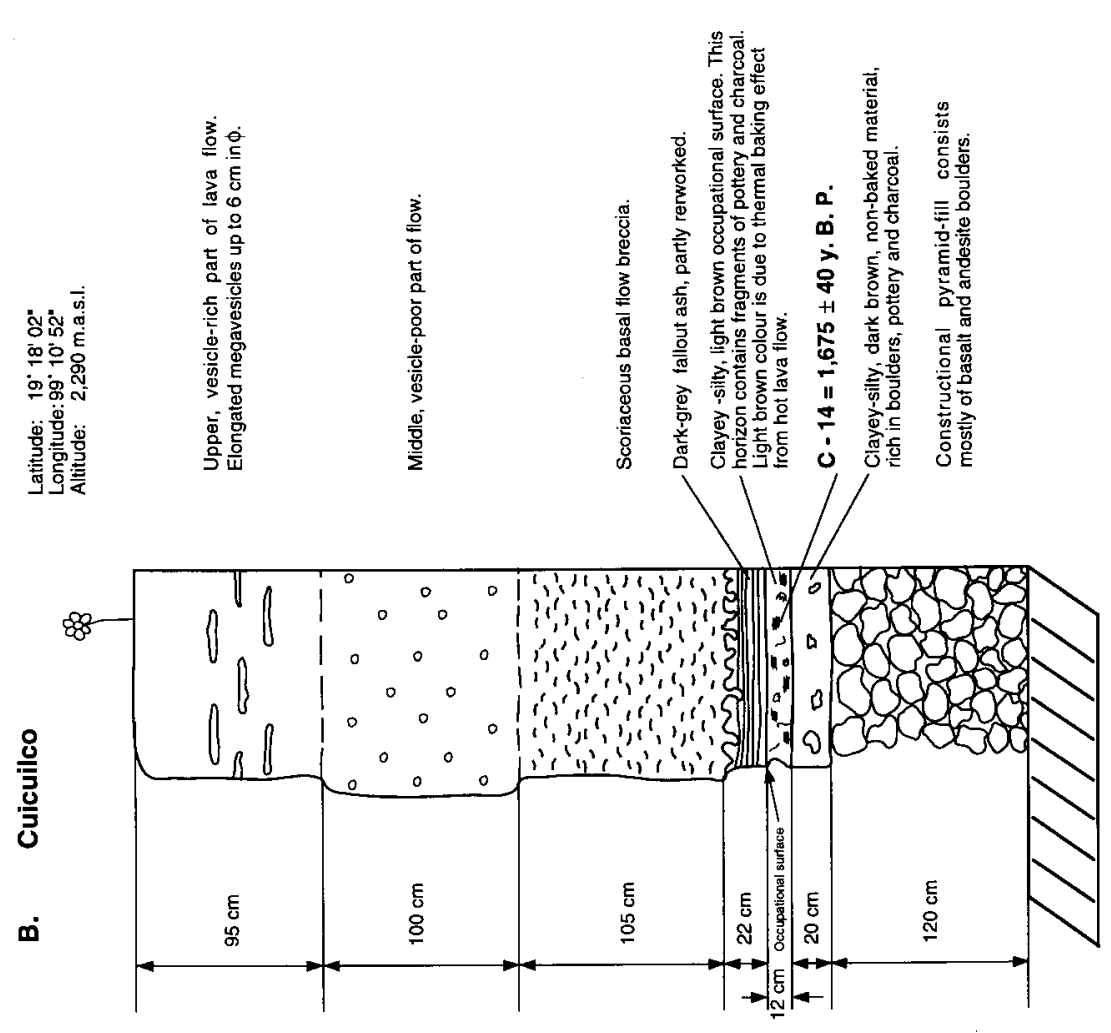

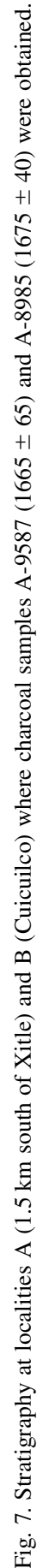

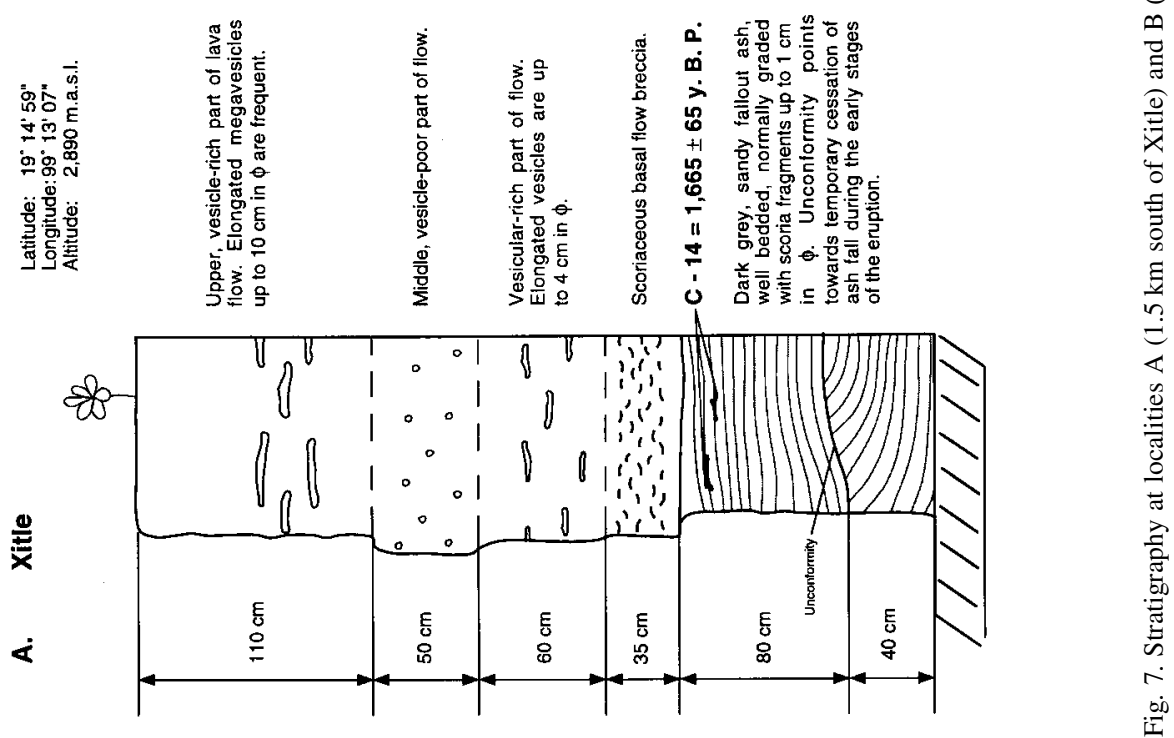




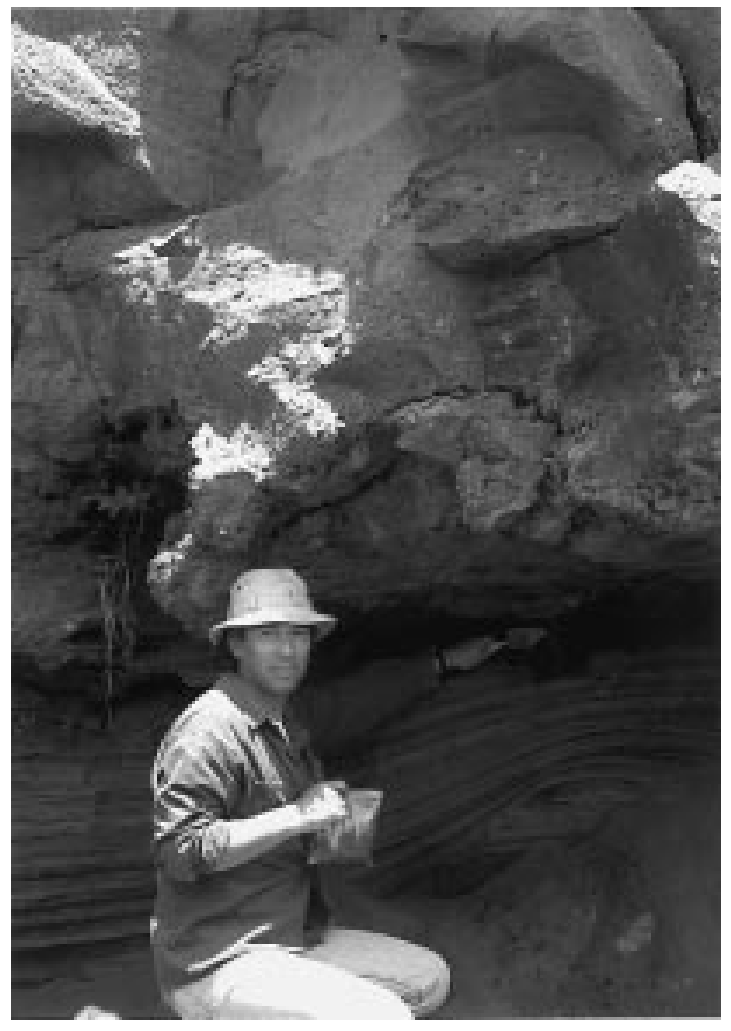

Fig. 8. Photograph showing the outcrop at locality A $(1.5 \mathrm{~km}$ south of Xitle) where key sample A-9587 (1665 \pm 65$)$ was found embedded within Xitle's scoriaceous tephra fallout layers immediately below the lava flow.

Aztecs and other cultures in the Valley of Mexico had flourished in the area now covered by lava (e.g. Alessio-Robles, 1939a,b). Cummings (1923a,b,c) believed that he had unearthed the oldest temple of the Americas (see also Walter, 1923). Cossío (1936) noticed that abundant archaeological material could be found stratigraphically above the lava flows, as well as within lava tubes. Later excavations revealed that the Cuicuilco pyramid was also used as a cemetery (e.g. Noguera, 1939; Hughes, 1956; Sánchez-Saldaña and Barrón-Sanromán, 1972). Furthermore, excavations did reveal that the final size of the pyramid was achieved only after an original, relatively small, structure was increased in height and diameter by at least five successive additions (e.g. Marquina, 1951; Haury, 1975). In 1956, Palerm (1961a,b) in the company of Wolf (1959) found evidence for the ancient use of perennial streams for irrigation. They discovered remains of two irrigation canals near Cerro Zacatépetl partly covered by Xitle lavas (Doolittle, 1990).

Based on pottery shards of Aztec style found on the lava flow and near Cerro Zacatépetl, as well as from early Spanish chronicles, Martínez del Río (1934) and Noguera (1940) concluded that the area of Xitle lavas was extensively used as a hunting ground during the Postclassic. In addition, pilgrimages to the lava, ritual offerings, and burials were performed. In 1960, PiñaChan (1967) discovered near Coyoacán, a site on the lava with Coyotlatelco style pottery shards, indicative of the Epiclassic (Toltec) period, which corresponds to the time following the demise of Teotihuacán (ca. AD 800).

As the radiocarbon method became available, Arnold and Libby (1951) and Libby (1955) dated material beneath flows from Xitle for the first time at $2422 \pm 250$ years BP. Since then, Xitle's eruption has been dated indirectly by the radiocarbon method by several authors. Most published radiocarbon ages cluster around 2000 years BP (e.g. Crane and Griffin, 1958; Heizer and Bennyhoff, 1958; Urrutia Fucugauchi, 1996; see Table 1). Points of debate have centered on stratigraphic issues related to the exact timing of the eruption and whether Cuicuilco was abandoned long before the eruption or as a result of it (e.g. Schavelzón, 1982, 1983; López-Camacho, 1991). More recent investigations (this paper, González et al., 2000) indicate that Xitle erupted around $1670 \pm 35$ years BP and that Cuicuilco was completely abandoned as a direct consequence of this eruption.

\section{Radiocarbon dating and stratigraphic relations}

Before the advent of radiocarbon dating, the ages of the Cuicuilco pyramid and Xitle lava flows were a matter of intense speculation. Ever since Cummings (1923a,b) demonstrated the artificial nature of the Cuicuilco mound, its age has been a subject of interest. On geologic and other grounds, he held that Cuicuilco fell into ruin some 8000 years BP (Cummings, 1926):

If the lava flow occurred at least two thousand years ago as attested by three most eminent geologists, Tempest Anderson, of England, Karl Wittich of Germany, and N.M. Darton of 


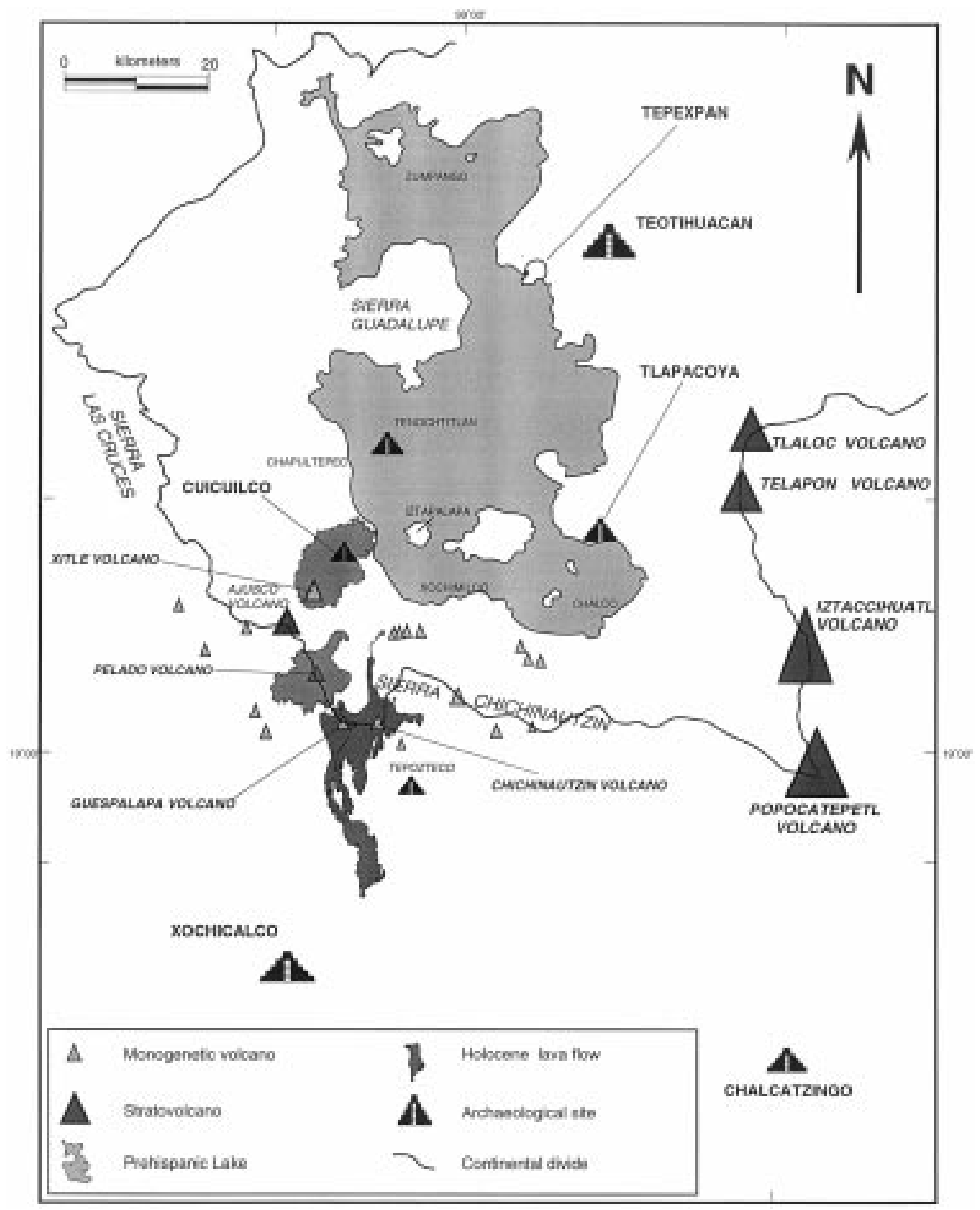

Fig. 9. Sketch map showing the Basin of Mexico and location of Prehispanic settlements. The approximate extent of the Texcoco lake system is also shown.

the US Geological Survey, then the geological and cultural stratification of the deposits lying between the base of Cuicuilco and the lava indicate the lapse of a much longer period of time between the building of the temple and the eruption of Xitle and the formation of the Pedregal. Eight thousand years is a very conservative estimate of the time that has elapsed since the 
primitive people toiled up the slopes of Cuicuilco and reared a mighty temple to their gods.

Many scholars (including the renowned geologists consulted by Cummings) were reluctant to accept this high estimate for a variety of reasons. Radiocarbon dates of wood charcoal collected from cultural deposits below the lava flow, compared with dates and the stratigraphy of other ruins, clearly demonstrated the need to drastically revise the 8000 year estimate toward the present. A first date (all dates mentioned hereafter are listed in Table 1) of $2422 \pm 250$ years BP (C-200) obtained on charcoal collected by De Terra under the lava was published for Cuicuilco (Arnold and Libby, 1951; Libby, 1955). This date is among the first dates ever determined by this method, which at that time was in its early stages of development. No detailed stratigraphic setting was given, but even so it was believed that the lava flow occurred around 400 $\mathrm{BC}$ and that the disaster had destroyed the town of Cuicuilco.

In respect to this breakthrough, De Terra (1951) wrote: "Sample 200 is of special interest since it came from a pottery level below the Pedregal lava, south of Mexico-City. The exact locality is south of the pyramid of Cuicuilco and left of the entrance of an underground passage leading under the lava in a southeasterly direction. The lava is here underlain by dark cinder, two to six inches thick, below which is loose yellowish soil with potsherds and figurines of Late Archaic (Ticoman phase) type, and charcoal. It is generally assumed that the pyramid of Cuicuilco, being partly buried by the lava is of that culture period. At long last, the controversy raging over the age of the pyramid and lava has been decided, and, it should be noted, in favour of the geologists who could not imagine the lava to have been much older than say 2000 years."

Comparison of the cultural remains from Cuicuilco with those of other Preclassic sites in the central Mexican highlands demonstrated the fact that Cuicuilco, at least the final period of its use before the lava came could be classified as late in that horizon, about 500-200 BC (Piña Chan, 1955). The limited collections of pottery available at that time hinted that the roots of Cuicuilco might dip back to 1000 BC. Unfortunately, all the Cuicuilco excavations were undertaken in constructed mounds built of sterile or mixed fill. Therefore, many layers were often subject to variable interpretation.

Later, Heizer and Bennyhoff (1958) reported substantially younger dates from charcoal collected from mounds near Cuicuilco exposed by commercial quarrying operations of the lava flows. This new locality of interest had been exposed in the Peña Pobre quarry about $0.5 \mathrm{~km}$ west of the pyramid. Six low earth mounds had been partially uncovered by 1957 , and their excavations confirmed the artificial nature of the mounds before their destruction by quarrying operations. In order to distinguish this Peña Pobre locality from the Cuicuilco pyramid with its adjacent mounds (Cuicuilco A), the western group of 11 mounds was referred to as Cuicuilco B (Heizer and Bennyhoff, 1972). It was determined that the mounds of Cuicuilco B were contemporaneous with an extension of Cuicuilco itself. In January 1957, two wood charcoal samples (Nos. M-663 and M-664) from below the Pedregal were collected from occupation deposits near mound 2 at Cuicuilco B, and were dated by the University of Michigan Laboratory at $2040 \pm 200$ and $1430 \pm 200$ years BP, respectively (Crane and Griffin, 1958; Heizer and Bennyhoff, 1958). According to Heizer and Bennyhoff (1958) samples M-663 and M-664 were expected to be of the same age. They concluded that a laboratory error was probably made in treating one of the samples and suggested that the older (M-663) was more likely to be closer to the actual age of the eruption. Excavations in the immediate vicinity of Cuicuilco continued (Heizer and Bennyhoff, 1972) and a total of 23 radiocarbon dates were obtained from the analysis of subpedregal charcoal at several laboratories (Table 1).

Regarding the young ages, R.F. Heizer commented later in a paper by Fergusson and Libby (1964): "Sample UCLA 228 (1536 \pm 65 , Fergusson and Libby, 1963) is presumed to date the eruption of Xitle volcano, whose lava covered the already abandoned site of Cuicuilco, but seems too young by 200 or 300 years. Samples C-200 (2422 \pm 250 , Arnold and Libby, 1951) and M-663 (2040 \pm 200 , Crane and Griffin, 1958) came from the Cuicuilco archaeological deposits and therefore predate the eruption by some undetermined amount of time. Sample Y-437 (1925 \pm 60 , Deevey et al., 1959) probably does not date the eruption, since it seems to refer to the 
prepedregal archaeological deposit containing Ticomán pottery. Sample M-664 (1430 \pm 200 , Crane and Griffin, 1958) is also a pre-eruption archaeological date, but seems too young in any event."

Heizer and Bennyhoff $(1958,1972)$ concluded that the Cuicuilco complex represented one of the largest and oldest manifestations of a metropolitan type of society, and as such might mark the beginnings of urbanism in the highlands of central Mexico. In the Late Preclassic (600-200 BC) it became evident that Cuicuilco was the main center for a new ceramic tradition, which dominated the Valley of Mexico during this period and contributed to the Teotihuacán tradition. Based on archaeological evidence and radicarbon dates they were able to distinguish several occupational phases at Cuicuilco (see also Fig. 6). In the Cuicuilco IV phase (200-100 BC) of the Terminal Preclassic they could recognize a disruption in the Cuicuilco ceramic tradition, during which the previous uniformity of the Cuicuilco III phase was shattered and a number of localized cultures appeared in different parts of the Valley of Mexico. They found evidence for the destruction of the temple platforms at the Cuicuilco A pyramid and in two mounds at Cuicuilco B.

After partial abandonment, the Cuicuilco VA phase $(100 \mathrm{BC}-1 \mathrm{AD})$ marked the resurgence of the Cuicuilco tradition. New construction was undertaken at Cuicuilco characterized by the first rectangular platforms at Cuicuilco B, and an elevated west-oriented, cylindrical platform of adobe bricks at the Cuicuilco A pyramid. Elsewhere this phase witnessed the rapid emergence of Teotihuacán as a major ceremonial center and potential rival of Cuicuilco.

The next Cuicuilco VB phase (AD 1-150) was regarded as the final occupation phase, during or immediately after which the site was eclipsed by the new center of Teotihuacán. The rivalry between Cuicuilco and Teotihuacán led to the collapse of Cuicuilco near the end of the Cuicuilco VB phase and its abandonment as a functional ceremonial center by $\mathrm{AD} 150$.

Heizer and Bennyhoff (1972) hinted at the possibility that Xitle erupted during the Cuicuilco VB phase, but based on available evidence they suggested that a later eruption was responsible for the lava flow that covered Cuicuilco. They noted that before the Pedregal lavas engulfed Cuicuilco, it had apparently stood in neglect for some time. According to their observations, a cushion of earth and occupational debris had formed over the rock facing of the edifice. Later, Heizer and Bennyhoff (1972), based on the radiocarbon age of $1536 \pm 65$ years BP (UCLA-228) obtained by Fergusson and Libby (1963) from a root burned by the lava, suggested again that the eruption of Xitle and the related lava flow took place around AD 400. This meant that the final eruption of Xitle volcano, which resulted in the lava flow that covered much of the southwest Valley of Mexico, including Cuicuilco, could be placed with reasonable certainty within the Teotihuacán II-IIIA phase, well within the Classic period of Mesoamerican archaeology (Fig. 6).

Muller (1990) studied ceramic remains unearthed during the excavations at Cuicuilco B. She concluded that the oldest ceramics belong to the Middle Preclassic (1000-800 BC) and that Cuicuilco was abandoned between $150 \mathrm{BC}$ and $\mathrm{AD} 100$ as a result of an initial eruption of Xitle, which produced mainly ashfall. During a second hypothetical eruption of Xitle, several hundred years later, the lava finally covered Cuicuilco when the settlement was already in ruins. Her conclusions were based on diagnostic ceramics as old as the Protoclassic (Teotihuacán I phase, 150 BC$A D$ 100) that were found stratigraphically above the lava flow. This ceramic material was used for ritual offerings, placed on top of the lava flow by people coming from other places on religious pilgrimages. Apparently some of Muller's conclusions had been in circulation long before its final publication.

Subsequent radiocarbon dates obtained by several authors between 1978 and 1998 yielded ages clustering around 2000 years BP. In 1978, an analysis from a piece of wood collected beneath the lava in a quarry about $1.5 \mathrm{~km}$ southwest of the Olympic stadium, yielded an age of $1960 \pm 70$ years BP (Tx-3648 in White et al., 1990). The problem with this age was that the collector did not provide the laboratory with a description of the site or the stratigraphic position from which the wood was taken (S. Valastro, personal communication, 1993, cited in Córdova et al., 1994). Two radiocarbon assays obtained earlier showed similar ages: $1925 \pm 60$ years BP (Y-437) from a sample of sublava tree bark found in alluvium by Hans Lenz near Cuicuilco A (Deevey et al., 1959; Cook de Leonard, 1969), and $2040 \pm 200$ years BP (M-663), from $35-40 \mathrm{~cm}$ below the burned earth stratum 
(Crane and Griffin, 1958). Both ages correspond to cultural horizons according to comments provided by Heizer and Bennyhoff (1972). Córdova et al. (1994) took samples near Cuicuilco from an upper cultural horizon in contact with the Xitle ash that yielded ages of $2030 \pm 60 \quad(\mathrm{Tx}-7669)$ and $2090 \pm 70$ years вP (Tx-7668). These ages appear to pertain to the same stratigraphic level that Heizer and Bennyhoff (1958) dated as Cuicuilco V phase, based on the radiocarbon age of $2040 \pm 200$ years BP (M663). Córdova et al. (1994) believed that the variability among the radiocarbon ages might be due to problems inherent to the types of material dated. They assumed that the most accurate date for the eruption is $1536 \pm 65$ years BP or AD 415 (UCLA228), obtained by Fergusson and Libby (1963) on charcoal, which is the second youngest age yet obtained and according to them correlated well with the youngest archaeological materials found below the lava. Therefore they believed it to best represent the age of the eruption. In addition they supported the hypothesis that Cuicuilco was abandoned long before the Xitle eruption.

Later, Urrutia Fucugauchi (1996) provided an additional radiocarbon date of $1960 \pm 65$ years BP obtained from underneath the lava flow. After briefly discussing previously published dates, he discarded the two young ages of $1536 \pm 65$ and $1430 \pm 200$ years BP published by Fergusson and Libby (1963) and favored by Córdova et al. (1994) and suggested that his date represents the date of the eruption. Unfortunately he did neither describe the exact stratigraphic position of his sample, nor provide any further satisfactory explanation why his date should be preferred.

More recently, Cervantes and Molinero (1995) and Delgado et al. (1998) carried out geologic investigations at Xitle and provided additional dates from charcoal in soil below the ashfall layer. Samples A-7843 and A-7844 were obtained near the Comedor UNAM and yielded $1945 \pm 55$ and $1785 \pm 55$ years BP, respectively, while sample A-7743 south of Xitle yielded $2025 \pm 55$ years BP. They discarded the young age of $1785 \pm 55$ years BP assuming that it was contaminated by percolating groundwater that chemically enriched the sample in ${ }^{14} \mathrm{C}$ making it younger. In much the same way as earlier proposed by Urrutia Fucugauchi (1996) they statistically analyzed existing dates and concluded that the eruption occurred around 2000 years BP.

After detailed evaluation of all the radiocarbon dates published until 1998, it became clear that none of the charcoal samples dated were obtained from a stratigraphic context, clearly indicating production of the charcoal by ignition from Xitle's incandescent eruptive products. Most of the samples clustering around 2000 years BP were obtained from the paleosoil underlying the ash and lava and in many cases stratigraphic relations described were ambiguous. In 1997 two charcoal samples collected by the author of the present article were obtained from stratigraphic contexts pointing toward the hot scoria as the source of heat for charcoal production. Both samples were analyzed by Chris Eastoe at the University of Arizona radiocarbon laboratory and corrected for ${ }^{13} \mathrm{C}_{\mathrm{PDB}}(\%)$. Sample A-9587 consisted of cm-sized fragments of wood charcoal collected at an outcrop located $1.5 \mathrm{~km}$ south of Xitle's cone (Fig. 5) and yielded an age of $1665 \pm 65$ years $\mathrm{BP}\left({ }^{13} \mathrm{C}_{\mathrm{PDB}}=-23.6\right)$. The wood charcoal was found embedded within a wellstratified, dark gray, scoriaceous sandy ashfall sequence directly underlying one of Xitle's lava flows (Figs. 7 and 8). The only plausible way to explain the occurrence of wood charcoal within the fallout sequence is by the fall of ignited branches from the burning forest trees at the time of the eruption. This means that the fallout tephra and the charcoal were emplaced simultaneously. Since the fallout ash and scoria were undoubtedly produced by Xitle, it can be concluded with great confidence that this age corresponds to the time of the eruption. On the other hand, sample A-8985 yielded an age of $1675 \pm 40$ year BP $\left({ }^{13} \mathrm{C}_{\mathrm{PDB}}=-23.3\right)$ and was collected at a trench dug adjacent to the Cuicuilco pyramid by archaeologist A. Pastrana in 1996 (González et al., 2000; see also Fig. 7). The cm-sized charcoal sample was found at the contact between the gray sandy Xitle fallout ash underlying the lava and the thermally baked paleosoil. This charcoal was therefore most probably also produced by the heat of Xitle's products. The compatibility of both dates enhances confidence in them and allows calculation of a combined age of $1670 \pm 35$ year BP (AD 245-315) for Xitle's eruption. This confirms the hypothesis that Xitle erupted much later than ca. 2000 years BP (the date most frequently accepted by previous investigators). 


\section{Discussion}

The Upper Preclassic and Lower Classic periods of Mesoamerican archaeology are characterized by the transition of small tribal villages with few larger ceremonial centers whose economy was based on the cultivation of maize and other crops into more stratified societies with much larger urban centers (e.g. Heydenreich, 1975). Toward the end of the Preclassic, Teotihuacán and Cuicuilco were the dominant urban centers in the Basin of Mexico (Fig. 9). By ca. 300$100 \mathrm{BC}$ they were very similar in size, character, and regional impact (Sanders et al., 1979). Both were a major demographic focus related to the high productivity of rainfall agriculture and small-scale water-control technologies. At this time Cuicuilco reached its maximum size and architectural complexity. Sanders et al. (1979) estimated a settlement area of at least 400 ha and a minimum population of about 20,000 people. During the period 100 BC-AD 100 Teotihuacán emerged as a center of extraordinary size and population. The great majority (80-90\%) of the population of the entire Basin of Mexico was located at Teotihuacán. At the same time Cuicuilco either vanished or decreased to a small center (Sanders et al., 1979).

Numerous interpretations have been offered to put Xitle's eruption into the archaeological context. For example:

(1) One hypothesis suggests that the downfall of Cuicuilco was directly attributable to the eruption of Xitle ca. 2000 years BP. As a result, Cuicuilco's population abandoned the southern margins of the Basin of Mexico and Teotihuacán emerged as the region's dominant city (e.g. Sarmiento, 1994).

(2) Another hypothesis (Piña-Chan, 1967; Heizer and Bennyhoff, 1972; Haury, 1975; Sanders et al., 1979; Córdova et al., 1994) explains the abandonment of Cuicuilco as a result of the rise of Teotihuacán in the northern part of the Basin of Mexico. According to this hypothesis, Teotihuacán absorbed a large part of the regional population and represented a neighbor hostile to Cuicuilco. Accordingly, Cuicuilco was already abandoned when the eruption of Xitle occurred.

(3) A third hypothesis proposes that Cuicuilco's fall was due to the eruption of Xitle, which deposited ash and lava over the city ca. 2000 year BP. As one result,
Teotihuacán emerged. Several hundred years later, another eruption from Xitle completed the job, burying the city entirely (e.g. Blanton et al., 1981; Muller, 1990; Navarrete, 1991).

None of the above hypotheses is compatible with all geologic evidence. Because Xitle is a monogenetic volcano, initial strombolian activity produced ashfall that was shortly after followed by the outpouring of lava in the form of successive flows. The time lapse between the initial ashfall and the arrival of successive flow fronts at Cuicuilco was relatively short and could have lasted from a few days to a maximum of a few years. This is confirmed by the absence of soil or archaeological material between the ashfall layer and the overlying lava flows. So far no evidence pointing toward the occurrence of two eruptions at Xitle has been found, as observed first by Ordoñez (1939). This means that Cuicuilco's final destruction was the result of Xitle's single and only eruption during which the entire "Pedregal" was formed. Of course, Cuicuilco could have been abandoned prior to the eruption due to other causes.

The great variability of radiocarbon ages, ranging from $400 \mathrm{BC}$ to $\mathrm{AD} 400$, is most likely the result of sampling from different stratigraphic levels and contexts. Although the archaeological evidence and radiocarbon ages seem to confirm that ash and lava blanketed the site of Cuicuilco as late as AD 245-315 (favored in this study) or maybe even AD 415 (Heizer and Bennyhoff, 1972), there still is a problem as to whether Cuicuilco could have been abandoned earlier.

Although ages younger than 2000 years BP for charcoal underneath the lava were determined since the early 60 s there has been a general reluctance to accept the accuracy of these young dates. Part of the reason for such reluctance may be a feeling that older is "better". Above all, the striking clustering of ages around 2000 years BP requires an explanation. The most popular explanation has been the invocation of a two-phase eruption of Xitle, which supposedly first produced the ashfall and several centuries later produced the lava flow that finally destroyed Cuicuilco (e.g. Blanton et al., 1981). Since this hypothesis is untenable on geologic observations described above, another reason needs to be sought. This might lie in the processes involved in the emplacement of the relatively fluid pahoehoe lava. Besides being erosive at some places (e.g. Ordoñez, 
1939), the Xitle lava was extremely hot and baked the underlying soil which shows intense temperature alteration at many places. The top $10-20 \mathrm{~cm}$ of the paleosoil display a brick-red color and strong induration. Curiously enough, this hardened layer lacks charcoal at most places. This means that most (but not all) of the vegetation existing at the time of lava-flow emplacement was combusted almost completely and transformed into gases without leaving much noticeable charcoalized remains. On the other hand, deeper soil levels containing older organic material (including charcoal) had little access to oxygen in addition to being thermally sufficiently isolated. For this reason, deeper soil levels contain more abundant charcoal that is not related to Xitle.

Thermal and mechanical effects of the lava on pottery shards were already noticed by Noguera (1939) and Ordoñez (1939). Noguera (1939) describes pottery fragmented by the load of the lava and baked due to the high temperature at depths exceeding $1 \mathrm{~m}$ under the lava. Under these circumstances, pottery found directly below the lava lost stylistic attributes normally used for making time correlations by archaeologists. He noticed that near the lava, pottery shards were more reddish in color. In addition, they were more porous and had lost their paint and surface polish, while shards at greater depths remained unchanged.

Another fact that should be kept in mind, is the use of explosives in removing the lava around the circular pyramid during its earliest exploration by Cummings. This procedure destroyed important stratigraphic evidence, especially for the period that immediately preceded lava flow emplacement. According to Marquina (1951), up to $6 \mathrm{~m}$ of the outer shell of the pyramid are missing. This means that the outer walls observable today represent reconstructed walls of an inner structure of the original edifice. The destruction and alteration of the youngest archaeological remains under the lava makes it difficult to reconstruct Cuicuilco's immediate past prior to the eruption.

Despite this, there is evidence that the decline of Cuicuilco's population took place well before the area was covered by ash and lava. In this context it should be mentioned that Popocatépetl experienced a major cataclysmic eruption dated between ca. 2200 and 2000 years BP $(250-50$ BC) as revealed by recent studies (Siebe et al., 1996; Plunket and Uruñuela, 1998; Panfil et al., 1999). This plinian eruption had a magnitude of VEI $=6$ and completely devastated large areas around the volcano, including several Preclassic settlements (e.g. the site of Tetimpa described by Plunket and Uruñuela, 1998). Although the eastern slopes of the volcano were most severely affected by plinian fallout, the NW slopes were also devastated by pyroclastic flows. Survivors in the Valley of Puebla and in the Amecameca-Chalco region located in the SE part of the Basin of Mexico had to migrate to other living grounds. Sanders et al. (1979) mention that between $100 \mathrm{BC}$ and AD 100, ca. $80-90 \%$ of the population of the entire Basin of Mexico nucleated at Teotihuacán and that the population in the southern part of the basin was reduced substantially. Popocatépetl's eruption certainly played a role in this process although it did not affect Cuicuilco directly.

\section{Conclusions}

Organic material found conveniently not far below the base of the lava was believed to be associated with the eruption of Xitle volcano and dated early during the development of the radiocarbon method (Arnold and Libby, 1951; Libby, 1955). This date of $2422 \pm 250$ years BP (C-200, Table 1$)$ remained as the most frequently quoted age for the Xitle eruption in subsequent studies. Several additional studies (e.g. Heizer and Bennyhoff, 1958, 1972; Córdova et al., 1994) supported the much younger date reported by Fergusson and Libby (1963) of $1536 \pm 65$ years BP (UCLA-228) for the Xitle eruption. All ages older than $1790 \pm 65$ years BP (Table 1) were obtained from stratigraphic levels that range from $10 \mathrm{~cm}$ to almost $7 \mathrm{~m}$ below the contact of the scoriaceous ashfall with the paleosoil. The group of ages around 4000 years BP is mainly formed by dates obtained in the Cuicuilco archaeological excavations from horizons between about 4 and $7 \mathrm{~m}$ below the lava. They can be related to early human occupation (Tlalpan stages, Fergusson and Libby, 1963). The group clustering around 2000 years BP was obtained from samples in the paleosoil underneath the ashfall and lava. This date of ca. 2000 years BP has also been wrongly proposed as the age of the Xitle eruption 
(e.g. Heizer and Bennyhoff, 1958; White et al., 1990; Urrutia Fucugauchi, 1996; Delgado et al., 1998). Based on two new dates obtained on charcoal produced directly by the eruption it is proposed here that Xitle's lavas flooded around AD 245-315 one of the earliest metropolitan areas in the New World. At this time, Cuicuilco was already on its decline for reasons that are not well understood. A cataclysmic eruption at Popocatépetl around 22002000 years BP. (200-0 BC) certainly contributed to the depopulation of the southern Basin of México and nucleation at Teotihuacán. Ironically, during the past five decades Xitle's sterile lava flows have been reclaimed almost entirely by Mexico-City's urban growth. Urbanization is today quickly creeping up the slopes of Sierra Chichinautzin, a volcanic field that could potentially give birth to another volcano in the future. Excavations related to civil-engineering projects are producing every day gorgeous outcrops cutting through young lava flow sequences and ultimately laying the foundations for future archaeological sites.

\section{Acknowledgements}

Support for analytical work and field studies was provided by grants from Consejo Nacional de Ciencia y Tecnología (CONACYT-27994-T) and UNAMDGAPA-IN101199. I want to thank Chris Eastoe at the Radiocarbon Laboratory in Tucson, Arizona for promptly dating charcoal samples, Virgilio Rodríguez and Ignacio Hernández for drawing the figures, Mike Abrams for providing Landsat imagery, Silvia González and Alejandro Pastrana for fruitful discussions, and Doris Heyden for reviewing an early version of the manuscript. Editorial handling by Greg Valentine and reviews by Wendell Duffield and Matthew Heizler were very helpful and are greatly appreciated.

\section{References}

Alessio-Robles, C., 1939a. Importancia arqueológica del Pedregal de San Angel. Investigaciones Históricas 1 (1), 293-301.

Alessio-Robles, C., 1939b. Importancia arqueológica del Pedregal de San Angel. Investigaciones Históricas 1 (2), 162-169.
Arnold, J.R., Libby, W.F., 1951. Radiocarbon dates. Science 113, $111-120$.

Badilla-Cruz, R.R., 1977. Estudio petrológico de la lava de la parte noreste del Pedregal de San Angel, D.F. Boletín de la Sociedad Geológica Mexicana 38, 40-57.

Beyer, H., 1918. Sobre antigüedades del Pedregal de San Angel. Memorias de la Sociedad Científica Antonio Alzate, México 37, $1-16$.

Blanton, R.E., Kowalewski, S.A., Feinman, G., Appel, J., 1981. Ancient Mesoamerica. Cambridge University Press, Cambridge, 300 pp.

Bloomfield, K., 1975. A late-Quaternary monogenetic volcano field in central Mexico. Geologische Rundschau 64, 476-497.

Bullard, F.M., 1984. Volcanoes of the Earth, 2nd ed. University of Texas Press, Austin, TX, 629 pp.

Cañón-Tapia, E., Walker, G.P.L., Herrero-Bervera, E., 1995. Magnetic fabric and flow direction in basaltic Pahoehoe lava of Xitle volcano, Mexico. Journal of Volcanology and Geothermal Research 65, 249-263.

Cervantes, P., Molinero, R.J., 1995. Eventos volcánicos al Sur de la Ciudad de México. Tesis de Licenciatura, Facultad de Ingeniería, UNAM, $74 \mathrm{pp}$.

Cook de Leonard, C., 1969. Sobre antigüedades del Pedregal de San Angel, comentarios a los artículos de Hermann Beyer, El Mexico Antiguo, vol. 11, Sociedad Alemana Mexicanista, pp. 575-582.

Córdova, C., Martin del Pozzo, A.L., López Camacho, J., 1994. Paleolandforms and volcanic impact on the environment of prehistoric Cuicuilco, southern Mexico City. Journal of Archaeological Science 21, 585-596.

Cossío, J.L., 1936. Una zona arqueológica del Pedregal de Coyoacán, D.F. Boletín de la Sociedad Mexicana de Geografía y Estadística, México 45, 251-267.

Crane, H.R., Griffin, J.B., 1958. University of Michigan radiocarbon dates III. Science 128, 1117-1123.

Cuervo-Márquez, C., 1928. El adoratorio de Tlalpan. Memorias de la Sociedad Científica Antonio Alzate 49, 191-199 (México).

Cummings, B., 1923a. Cuicuilco. Ethnos II (1), 90-94.

Cummings, B., 1923b. Cuicuilco, the oldest temple discovery in North America. Art and Archaeology 16, 51-58.

Cummings, B., 1923c. Ruins of Cuicuilco may revolutionize our history of Ancient America: lofty mound sealed and preserved by great lava flow for perhaps seventy centuries is now being excavated in Mexico. National Geographic Magazine 40, 203220.

Cummings, B., 1926. Cuicuilco and the Archaic culture of Mexico. Scientific Monthly 23, 289-304.

Cummings, B., 1933. Cuicuilco and the Archaic culture of Mexico. University of Arizona Bulletin 4, 56 pp.

Deevey, E.S., Gralenski, L.J., Hoffren, V., 1959. Yale natural radiocarbon measurements IV. Radiocarbon 1, 144-172.

Delgado, H., Molinero, R., Cervantes, P., Nieto-Obregón, J., Lozano-Santa Cruz, R., Macías-González, H.L., MendozaRosales, C., Silva-Romo, G., 1998. Geology of Xitle volcano in southern Mexico-City. A 2000 year-old monogenetic volcano in an urban area. Revista Mexicana de Ciencias Geológicas 15 (2), 115-131 (Instituto de Geología, UNAM, México). 
De Terra, H., 1951. Comments on radiocarbon dates from Mexico. Memoirs of the Society for American Archaeology 8, 33-36.

Díaz-Lozano, E., 1925. Cultura post-neolítica del Pedregal de San Angel, México. Ethnos (Epoca III, T-I) 1 (2), 25-35 (México).

Díaz-Lozano, E., 1925. Excavaciones practicadas en el pueblo de Coyoacán, D.F., Ethnos (Epoca III, T-I) 3 (4) 60-66 (México).

Doolittle, W.E., 1990. Canal irrigation in prehistoric Mexico. The sequence of technological change, University of Texas Press, Austin, TX, 205 pp.

Fergusson, G.J., Libby, W.F., 1963. UCLA radiocarbon dates II. Radiocarbon 5, 1-22.

Fergusson, G.J., Libby, W.F., 1964. UCLA radiocarbon dates III. Radiocarbon 6, 318-339.

Foshag, W.F., González, R.J., 1956. Birth and development of Paricutín volcano, Mexico. US Geological Survey Bulletin 965D, $355-489$.

Fries, C., 1962. Bosquejo geológico de las partes central y occidental del Estado de Morelos y areas contiguas de Guerrero y México. 20th International Geological Congress, México, Fieldtripguide No. C-9, UNAM, México, pp. 17-53.

Gamio, M., 1920. Las excavaciones del Pedregal de San Angel y la Cultura Arcaica de México. American Anthropologist (New Series) 22, 127-143.

González, S., Pastrana, A., Siebe, C., Duller, G., 2000. Timing of the Prehistoric eruption of Xitle volcano and the abandonment of Cuicuilco pyramid, southern Valley of Mexico. In: McGuire, B., Griffiths, D., Stewarts, I. (Eds.), The Archaeology of Geological Catastrophes. Geological Society of London Special Publication 171, 205-224.

Gunn, B.M., Mooser, F., 1971. Geochemistry of the volcanics of central Mexico. Bulletin of Volcanology 34, 577-616.

Haury, E., 1975. Cuicuilco in retrospect. The Kiva 41, 195-200.

Heizer, R.F., Bennyhoff, J.A., 1958. Archeological investigations of Cuicuilco, Valley of Mexico, 1957. Science 127, 232-233.

Heizer, R.F., Bennyhoff, J.A., 1972. Archaeological excavations at Cuicuilco, Mexico, 1957. National Geographic Society Research Reports, 1955-1960, 93-104.

Herrero, E., Pal, S., 1978. Paleomagnetic study of Sierra de Chichinautzin. Geofisíca Internacional 17, 167-180.

Heydenreich, D., 1975. Los primeros centros ceremoniales. La cuenca de México. In: Piña Chán, R. (Ed.), Del nomadismo a los centros ceremoniales. Mexico, Panorama histórico y cultural, VI. INAH, México, pp. 263-281.

Hughes, J.T., 1956. Stone crosses with a Cuicuilco burial. American Antiquity 22, 80-82.

Kirianov, V.Y., Koloskov, A.B., De la Cruz, S., Martin del Pozzo, A.L., 1990. The major stages of manifestation of recent volcanism in the Chichinautzin zone. USSR Academy of Sciences, Geological series 311, 432-434.

Kroeber, A.L., 1925. Archaic culture horizons in the Valley of Mexico. University of California Publications in American Archaeology and Ethnology 17, 373-408.

Libby, W.F., 1955. Radiocarbon dating, 2nd ed. University of Chicago Press, Chicago.

López-Camacho, J., 1991. La estratigrafía de la pirámide de
Cuicuilco en retrospectiva, Cuicuilco, 27, Escuela Nacional de Antropología e Historia, Mexico-City, pp. 35-46.

Lugo Hubp, J., 1984. Geomorfología del Sur de la Cuenca de México, Serie Varia, vol. 1, no. 8, Instituto de Geografía, UNAM, México-City, 95 pp.

Luhr, J.F., Simkin, T., 1993. Paricutín, the volcano born in a cornfield, Geosciences Press, Phoenix, AZ, 427 pp.

Maldonado Koerdell, M., 1954. Formación y caracteres del Pedregal de San Angel, , Tlatoani, vol. 8, Escuela Nacional de Antropología e Historia, Mexico (pp. 12-17).

Marquina, I., 1951. Arquitectura prehispánica. Memorias del INAH 1, 47-55 (México).

Martin del Pozzo, A.L., 1982. Monogenetic vulcanism in Sierra Chichinautzin, Mexico. Bulletin of Volcanology 45, 9-24.

Martínez del Río, P., 1934. Les chasses "Chacu" au Mexique et les ruines du Zacatepec. Journal de la Societé des Americanistes, Paris 26, 293-300.

Millón, R., 1994. Teotihuacán. Scientific American Special Issue on Ancient Cities 5 (1), 138-148.

Mooser, F., 1963. Historia tectónica de la Cuenca de México. Boletín de la Associación Mexicana de Geólogos Petroleros 15, 239-245.

Mooser, F., Nairn, A.E.M., Negendank, J.F.W., 1974. Palaeomagnetic investigations of the Tertiary and Quaternary igneous rocks: VIII. A paleomagnetic and petrologic study of volcanics of the Valley of Mexico. Geologische Rundschau 63, 451-483.

Muller, F., 1990. La cerámica de Cuicuilco B. Un rescate arqueológico. Instituto Nacional de Antropología e Historia, Colección Científica, Serie Arquelogía No. 186, 285 pp.

Navarrete, C., 1991. Cuicuilco y la arqueología del Pedregal: Crónica de un desperdicio Arqueología 5, pp. 69-84.

Newhall, C.G., Self, S., 1982. Volcanic explosivity index (VEI): an estimate of explosive magnitude for historical volcanism. Journal of Geophysical Research 87, 1231-1238.

Noguera, E., 1938. Las tumbas de Copilco, Mapa, Mexico, vol. 5, no. 53, pp. 17-19.

Noguera, E., 1939. Excavaciones en Cuicuilco. XXVII Congreso Internacional de Americanistas, México, INAH-SEP, vol. 2, pp. 210-221.

Noguera, E., 1940. Los monumentos arqueológicos y la cerámica de Zacatepec. Revista Mexicana de Estudios Antropológicos 4 (12), 16-43.

Nuttall, Z., 1925. La cerámica descubierta en Coyoacán, D.F. Ethnos (Epoca III, T-I) 3 (4) 82-86 (México).

Ordoñez, E., 1890. El Pedregal de San Angel. Memorias de la Sociedad Científica Antonio Alzate, México 4, 113-116.

Ordoñez, E., 1895. Las rocas eruptivas del suroeste de la Cuenca de México. Boletín del Instituto Geológico de México 2, 5-46.

Ordoñez, E., 1907. Excursion au Pedregal de San Angel. Compte Rendu de la X Session du Congress Geol. Intern. Mexico. Fascicule 10, 1303-1304.

Ordoñez, E., 1939. Las ruinas de Cuicuilco. Revista Mexicana de Ingeniería y Arquitectura 17 (2), 91-108.

Palerm, A., 1961a. Distribución del regadío prehispánico en el area central de Mesoamérica. Revista Interamericana de Ciencias Sociales 1, 242-267. 
Palerm, A., 1961b. Sistemas de regadío prehispánico en Teotihuacán y en el Pedregal. Revista Interamericana de Ciencias Sociales 1 (2), 297-302.

Panfil, M.S., Gardner, T.W., Hirth, K.G., 1999. Late holocene stratigraphy of the Tetimpa archaeological sites, northeast flank of Popocatépetl volcano, central Mexico. Bulletin of the Geological Society of America 111 (2), 204-218.

Pearson, G.W., Stuiver, M., 1993. High precision bidecal calibration of the radiocarbon time scale, 500-2500 BC. Radiocarbon 35, 24-34.

Piña Chan, R.P., 1955. Las culturas Preclásicas de la Cuenca de México, , Fondo de Cultura Económica, 115 pp.

Piña-Chan, R., 1967. Un complejo Coyotlatelco en Coyoacán, México, D.F. Anales de Antropología 4, 141-160 (UNAM, Instituto de Investigaciones Históricas, México).

Plunket, P., Uruñuela, G., 1998. Preclassic household patterns preserved under volcanic ash at Tetimpa, Puebla, Mexico. Latin American Antiquity 9 (4), 287-309.

Porter Weaver, M., 1993. The Aztecs, the Maya, and their predecessors, Academic Press, New York, 567 pp.

Sánchez-Saldaña, P., Barrón-Sanromán, R., 1972. Dentición de los pobladores prehispánicos en Cuicuilco. Boletín INAH 3, 45-52.

Sanders, W.T., Parsons, J.R., Santley, R.S., 1979. The Basin of Mexico, ecological processes in the evolution of a civilization, Academic Press, New York, 561 pp.

Sarmiento, G., 1994. La creación de los primeros centros de poder. In: Manzanilla, L., López-Luján, L. (Eds.). El México antiguo, sus áreas culturales, los orígenes y el horizonte Preclásico, Historia antigua de México, vol. 1. Miguel Angel Porrúa, México, pp. 247-277.

Scandone, R., 1979. Preliminary evaluation of the volcanic hazard in the southern Valley of Mexico. Geofísica Internacional 18, 21-35.

Schavelzón, D., 1982. La pirámide de Cuicuilco: Arqueología de una polémica. Cuicuilco, Revista de la Escuela Nacional de Antropología e Historia, Mexico 9, 13-18.

Schavelzón, D., 1983. La pirámide de Cuicuilco. Album fotográfico 1922-1980, , Fondo de Cultura Económica, México, 113 pp.

Schmitter, E., 1953. Investigaciones petrológicas en las lavas del Pedregal de San Angel, México, D.F. Congreso Científico Mexicano, Memorias 3, 218-237.

Siebe, C., Abrams, M., Macías, J.L., Obenholzner, J., 1996. Repeated volcanic disasters in Prehispanic time at Popocatepetl, Central Mexico: past key to the future?. Geology 24 (5), 399402 (Geological Society of America, Boulder, CO).
Stuiver, M., Becker, B., 1993. High-precision decadal calibration of the radiocarbon time scale, AD 1950-6000 BP. Radiocarbon 35, $35-36$.

Stuiver, M., Pearson, G.W., 1993. High-precision decadal calibration of the radiocarbon time scale, AD 1950-500 BC and 25006000 BC. Radiocarbon 35, 1-23.

Swinamer, R.T., 1989. The geomorphology, geochemistry and petrogenesis of the volcanic rocks in the Sierra del Chichinautzin, Mexico. MSc thesis, Queen's University, Kingston, Ontario, Canada, 212 pp.

Urrutia Fucugauchi, J., 1996. Palaeomagnetic study of the XitlePedregal de San Angel lava flow, southern Basin of Mexico. Physics of the Earth and Planetary Interiors 97, 177-196.

Urrutia Fucugauchi, J., Martin del Pozzo, A.L., 1993. Implicaciones de los datos paleomagnéticos sobre la edad de la Sierra Chichinautzin, Cuenca de México. Geofísica Internacional 32, $523-$ 533.

Waitz, P., Wittich, E., 1910. Tubos de explosión en el Pedregal de San Angel. Boletín de la Sociedad Geológica Mexicana 7, 169186.

Wallace, P.J., Carmichael, I.S.E., 1999. Quaternary volcanism near the Valley of Mexico: implications for subduction zone magmatism and the effects of crustal thickness variations on primitive magma compositions. Contributions to Mineralogy and Petrology 135, 291-314.

Walter, P.A.F., 1923. The lava temple at Cuicuilco, El Palacio, School of American Research, Archaeological Institute of America, vol. 14, pp. 63-64.

White, S.E., Reyes-Cortés, M., Ortega-Ramírez, J., Valastro, S., 1990. El Ajusco: Geomorfología volcánica y acontecimientos glaciales durante el Pleistoceno superior y comparación con las series glaciales mexicanas y las de las Montañas Rocallosas, INAH-Colección Científica, Serie Arqueología, vol. 212, 77 pp.

Wittich, E., 1910. Neue Aufschlüsse im Lavafeld von Coyoacán bei Mexiko. Neues Jahrbuch für Mineralogie, Geologie und Paläeontologie 2, 131-137.

Wittich, E., 1916. Über Lavahöhlen im Pedregal von San Angel bei Mexiko. Neues Jahrbuch für Mineralogie, Geologie und Paläeontologie I, 126-133.

Wittich, E., 1919. Los fenómenos microvolcánicos en el Pedregal de San Angel. Memorias de la Sociedad Científica Antonio Alzate, México 38, 101-120.

Wolf, E., 1959. Sons of the shaking earth, University of Chicago Press, Chicago, 303 pp. 